\title{
Simple Flow Injection Amperometric System for Simultaneous Determination of Dipyrone and Paracetamol in Pharmaceutical Formulations
}

\author{
Wallans T. P. dos Santos, Denise T. Gimenes, Edimar G. N. de Almeida, \\ Sebastião de P. Eiras, Yaico D. T. Albuquerque, Eduardo M. Richter*
}

Instituto de Química, Universidade Federal de Uberlândia, Av. João Naves de Ávila, 2121, 38408-970 Uberlândia-MG, Brazil

\begin{abstract}
Este trabalho descreve uma metodologia simples empregando análise por injeção em fluxo com detecção amperométrica pulsada para determinação simultânea de dipirona (DI) e paracetamol (PCT) em formulações farmacêuticas. Os compostos são detectados através da aplicação de quatro pulsos de potencial (seqüenciais) em função do tempo. Dipirona é diretamente detectada em $+0,40 \mathrm{~V}$ e paracetamol indiretamente em $0,00 \mathrm{~V}$ através da redução do produto de oxidação $(N$-acetil- $p$ benzoquinonaimina) gerada eletroquimicamente em $+0,65 \mathrm{~V}$. O quarto pulso de potencial $(-0,05 \mathrm{~V})$ é aplicado para a regeneração ou limpeza do eletrodo de trabalho (carbono vítreo). A faixa linear de resposta foi otimizada em 9 a $45 \mathrm{mg} \mathrm{L}^{-1}$ para dipirona e em 6 a $30 \mathrm{mg} \mathrm{L}^{-1}$ para paracetamol. As regressões lineares para as duas curvas analíticas apresentaram excelentes coeficientes de correlação $(\mathrm{R}=0,999)$, assim como os resultados obtidos nos estudos de adição-recuperação ( $c$. $100 \%$ ). A freqüência analítica para a metodologia proposta foi calculada em 45 injeções hora com o consumo de $1,5 \mathrm{~mL}$ de solução por minuto. $\mathrm{O}$ desvio padrão relativo do sinal para 24 injeções sucessivas foi calculado em $0,4 \%$ para dipirona e $0,2 \%$ para paracetamol. O método proposto foi usado com sucesso para a determinação destes compostos em formulações farmacêuticas.
\end{abstract}

In this work a simple flow injection methodology with pulsed amperometric detection for simultaneous determination of dipyrone (DI) and paracetamol (PCT) in pharmaceutical formulations is described. The compounds are detected by applying four sequential potential pulses as function of the time. Dipyrone is directly detected at $+0.40 \mathrm{~V}$ and paracetamol indirectly at $0.00 \mathrm{~V}$ through the reduction of the oxidation product ( $N$-acetyl-p-benzoquinoneimine) electrochemically generated at $+0.65 \mathrm{~V}$. The fourth potential pulse $(-0.05 \mathrm{~V})$ is applied for the cleaning of the electrode surface (glassy carbon). The linear response range was optimized between 9 and $45 \mathrm{mg} \mathrm{L}^{-1}$ for dipyrone and 6 and $30 \mathrm{mg} \mathrm{L}^{-1}$ for paracetamol. Linear regression of these two series of experiments leads to excellent correlation coefficients $(\mathrm{R}=0.999)$ for both analytes and recoveries of around $100 \%$. The proposed methodology allows an analytical frequency of 45 injections $\mathrm{h}^{-1}$ with a consumption of $1.5 \mathrm{~mL}$ of solution per minute. The relative standard deviation for 24 successive injections of solutions containing DI and PCT was calculated as $0.4 \%$ and $0.2 \%$, respectively. The developed methodology was successfully used for the determination of dipyrone and paracetamol in pharmaceutical samples.

Keywords: simultaneous determination, dipyrone, paracetamol, flow injection analysis (FIA), multiple pulse amperometric detection

\section{Introduction}

Dipyrone (DI), also known as metamizol, is a widely used analgesic and antipyretic with proven efficiency in pharmaceutical formulations. ${ }^{1}$ Despite being restricted in some countries, like the United States, DI is commercially available in Brazil, mainly due to its strong analgesic effect and a relative

*e-mail: emrichter@iqufu.ufu.br low cost. ${ }^{2}$ In some drugs, DI is presented in combination with paracetamol (PCT), which is also an analgesic and antipyretic drug widely used in formulations for pain relief or fever reducer without causing gastric problems, such as aspirin. ${ }^{3}$ The combination of both drugs is indicated in order to enhance the effect by pharmacodynamics interaction, ${ }^{4,5}$ which may justify the presence of DI and PCT in the same formulation.

Due to the low cost of generic medicinal products 
compared to brand-name medicinal products, the generic pharmacies can be an alternative way for acquisition of these medicines by consumer. However, there are some obstacles that hinder the growth of this field, and the most significant one is the lack of credibility in the generic drugs. ${ }^{6}$ On the other hand, the development of analytical methods that are simpler, faster and present lower costs, to incentive systems for a quality control of commerciallyavailable drugs, can promote the growth of this area. Efficient methodologies for the analysis of commercial drugs are also extremely important for quality control in the pharmaceutical field.

Several works reported analytical methodologies for the determination of dipyrone or paracetamol. For dipyrone, procedures employing titration, ${ }^{7,8}$ chromatography, ${ }^{9,10}$ voltammetry, ${ }^{11}$ polarography, ${ }^{12}$ spectrophotometry, ${ }^{13,14}$ and flow methods using many detectors ${ }^{14-20}$ are described. For paracetamol, in the same manner, a considerable number of analytical methods are mentioned, as highlighted in a review recently published and other related works. ${ }^{3}$ However, few analytical methods are able to perform the simultaneous determination of DI and PCT, in cases where both compounds are concomitantly present in the sample. According to the US Pharmacopoeia (USP), ${ }^{21}$ when two or more active ingredients are present in a given formulation, the quantification must be carried out by high performance liquid chromatography (HPLC) with UV detection. Among the few references cited for simultaneous determination of DI and PCT, one of them mentions the use of titration, ${ }^{22}$ which requires prior stages of sample preparation and separation of the analytes, increasing significantly the time of analysis. Other methodologies applied HPLC-UV, ${ }^{9,23,24}$ based on official methods, which are expensive and usually require sample pretreatment, affecting the analytical frequency and producing significant quantities of organic solvents as waste. Thus, the development of procedures for faster and cheaper analyses, with selectivity and sensitivity comparable to the official methods, is a subject of great interest in this research area. ${ }^{25}$

Electroanalytical techniques are considered an alternative for the development of methods with reduced time and analysis costs, because they frequently enable the direct determination of electroactive compounds in complex samples. ${ }^{26}$ Among the electroanalytical methods, amperometric detection at constant potential coupled with FIA system provides good selectivity and high frequency for the analytical determination of many compounds. ${ }^{27,28}$ However, this method of detection is limited for cases in which the simultaneous determination of electroactive compounds at the same working electrode is required. Another limitation of amperometric detection at constant potential is related to the contamination of the electrode surface, for example, in the determination of phenols and derivatives ${ }^{29}$ and compounds of pharmaceutical formulations. ${ }^{30}$

Multiple pulse amperometric detection (MPA) coupled with flow injection analysis systems can be an alternative technique to prevent contamination of the electrode and allows simultaneous determination of electroactive compounds. This technique makes possible the acquisition of up to 10 successive ("simultaneous") amperograms at 10 different potential pulses of short duration (Software GPES - Autolab Eco Chemie). By using this software, the minimum time of application of each potential pulse is $30 \mathrm{~ms}$. MPA detection has already been used some time as detector in flow systems and chromatographic methods in order to implement the electrochemical cleaning of electrode surfaces during the analysis. ${ }^{27,28}$ In many articles this technique is also called pulsed amperometric detection. Although MPA is already available for some years, this technique has been little explored for simultaneous determination of electroactive compounds in FIA. Two studies were found in the literature in which this technique was used for this purpose. Chang and Huang ${ }^{31}$ used MPA for simultaneous determination of $\mathrm{Cd}^{2+}$ and $\mathrm{I}^{-}$or $\mathrm{Pb}^{2+}$ and $\mathrm{Br}$, whereas Surareungchai et al. ${ }^{30}$ described the simultaneous analysis of glucose and fructose. Recently, our research group demonstrated the possibility to use FIA with pulsed amperometric detection for the simultaneous determination of ascorbic acid and paracetamol in pharmaceutical formulations. ${ }^{32}$

In this work, we present for the first time a methodology for simultaneous determination of DI and PCT in pharmaceutical formulations using FIA with MPA detection. Studies to select the adequate potential pulses (waveform) for direct detection of dipyrone (DI) and indirectly paracetamol (PCT), as well for electrode surface cleaning are shown.

\section{Experimental}

\section{Reagents}

Solutions were prepared with deionized water $\left(18 \mathrm{M} \Omega \mathrm{cm}^{-1}\right)$ obtained from Milli-Q plus purification system (Millipore) and analytical grade reagents. Working PCT and DI standard solutions were prepared from SigmaAldrich (p.a. $\geq 99.0 \%$ ) and were prepared on the day of use by suitable dilutions with water. Acetic acid/potassium acetate $0.1 \mathrm{~mol} \mathrm{~L}^{-1}$ ( $\mathrm{pH} 4.7$ ) buffer solution was used as supporting electrolyte in the electrochemical experiments. Stock solutions containing $1000 \mathrm{mg} \mathrm{L}^{-1}$ of the respective drugs were prepared and diluted in buffer solution before all experiments. Commercial samples were acquired in local drugstores and prepared in the same electrolyte support. Each 
sample analysis was repeated four times. All experiments were conducted at constant temperature of $25^{\circ} \mathrm{C}$.

\section{Instrumentation}

The voltammetric and amperometric measurements were performed using a Potentiostat/Galvanostat PGSTAT 20 (Autolab - Eco Chemie) and a home-made electrochemical flow cell ("wall jet" type) with three incorporated electrodes. ${ }^{33}$ As reference, auxiliary, and working electrodes were used $\mathrm{Ag} / \mathrm{AgCl}, \mathrm{KCl}$ (sat.), ${ }^{34}$ a platinum wire, and a glassy carbon disk with $3 \mathrm{~mm}$ of diameter, respectively. Studies to establish the potential steps to be used for amperometric detection were performed by cyclic voltammetry using a scan rate of $50 \mathrm{mV} \mathrm{s}^{-1}$. The FIA system (single line) was composed with polyethylene tubes of $1 \mathrm{~mm}$ i.d. The flow rate $\left(1.5 \mathrm{~mL} \mathrm{~min}^{-1}\right)$ was controlled by the pressure generated by a water column. ${ }^{33}$ All experiments using MPA are presented after the subtraction of the constant background current (capacitive). The obtained data were processed off-line applying Origin 5.0 software (OriginLab Corporation).

\section{Titration experiments}

Results of the simultaneous determination of DI and PCT in commercial samples were compared with the ones obtained by the Pharmacopoeia method, such as the determination of dipyrone (iodometric titration), ${ }^{7}$ and sometimes using previously published methods, such as the determination of paracetamol by titration with $\mathrm{Ce}^{4+}$ solution..$^{22}$ The method for the determination of both drugs by titration was established as follows: first an aliquot of the sample was analyzed by iodometric titration in acetate buffer medium ( $\mathrm{pH}$ 4.7) for DI quantification in the presence of PCT, once PCT does not react with iodine in this medium. Then, another aliquot of the same sample was titrated with a standard solution of $\mathrm{Ce}^{4+}$. Both analytes are oxidized by $\mathrm{Ce}^{4+}$, and, taking into account the difference between the results of the two titrations, it is possible to quantify PCT in the sample.

\section{Results and Discussion}

\section{Electrochemical behavior of DI and PCT}

The electrode mechanism proposed in the literature for both analytes involves the transfer of protons. ${ }^{11,35}$ This suggests the influence of $\mathrm{pH}$ on the oxidation and reduction peak potentials for both analytes is similar. Therefore, preliminary studies of the electrochemical behavior of DI and PCT were performed using cyclic voltammetry and glassy carbon electrode in different buffer solutions such as: citric acid/citrate ( $\mathrm{pH} 3.0)$, acetic acid/acetate ( $\mathrm{pH} 4.7$ ), dihydrogen/hydrogen phosphate $(\mathrm{pH}$ 7.2) and boric acid/ borate $(\mathrm{pH}$ 9.2). The best conditions, with respect to the separation of the oxidation peaks and amperometric detection sensitivity of DI and PCT in FIA were obtained in acetate buffer medium ( $\mathrm{pH} 4.7$ ). Figure 1 presents the cyclic voltammograms in acetate buffer solution without (a) and with the addition of $3.0 \mathrm{mmol} \mathrm{L}^{-1}$ of DI (b) and PCT (c).

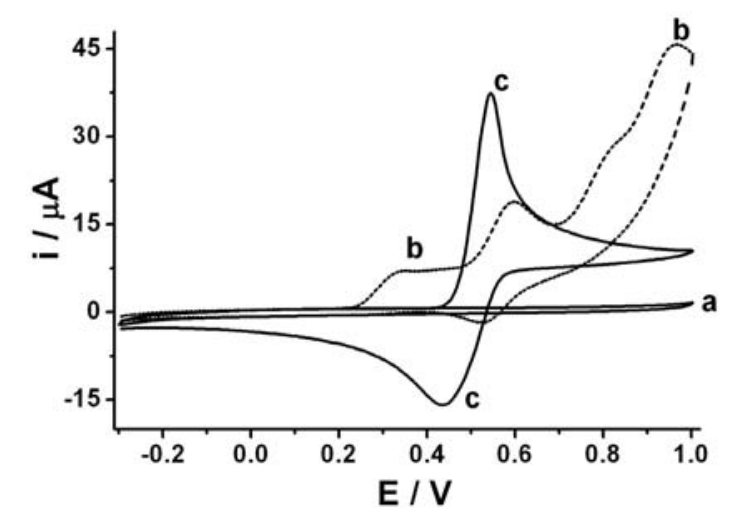

Figure 1. Cyclic voltammograms at a glassy carbon electrode in $0.1 \mathrm{~mol} \mathrm{~L}^{-1}$ acetic acid/acetate buffer ( $\mathrm{pH} 4.7$ ) (a) without and with the addition of $3 \mathrm{mmol} \mathrm{L}^{-1}$ of (b) DI and (c) PCT. Scan rate: $50 \mathrm{mV} \mathrm{s}^{-1}$; step potential: $5 \mathrm{mV}$.

Figure 1 shows that in this supporting electrolyte, DI presents four oxidation processes, partially in agreement with Cavalheiro et al. ${ }^{11}$ The first anodic peak occurs at $+0.33 \mathrm{~V}$, the second at $+0.60 \mathrm{~V}$, the third at $+0.81 \mathrm{~V}$ and, the fourth at $+0.96 \mathrm{~V}$. As can be seen, one of the oxidation products is reduced at $+0.53 \mathrm{~V}$, which to our knowledge was not reported in the literature. PCT, in turn, presents a reversible behavior with an anodic peak at $+0.54 \mathrm{~V}$ and the reduction of the product generated in the oxidation process ( $N$-acetyl-p-benzoquinoneimine, NABQ), at $+0.44 \mathrm{~V}^{35}$ The results obtained using glassy carbon as working electrode and acetic acid/acetate as supporting electrolyte proportioned a good separation $(c a .0 .2 \mathrm{~V})$ between the first oxidation peak of DI and the oxidation peak of PCT. It can also be observed that the NABQ reduction signal is significantly larger than the reduction signal of the oxidation product of DI. Based on these experimental results, initial studies were conducted for the simultaneous determination of DI and PCT with FIA and MPA detection.

Flow injection analysis (FIA) with multiple pulse amperometric (MPA) detection

Using the FIA method with amperometric detection at constant potential it is possible to analyze DI without 
interference of PCT setting a potential where only the oxidation of DI occurs, for example, at $+0.40 \mathrm{~V}$. However, for PCT determination, this method suffers from interference of DI. An alternative method proposed in this work is the use of MPA detection, which allows the sequential and fast ("simultaneous") acquisition of amperograms at different potentials. Thus, the proposal is to determine DI selectively by its direct oxidation and PCT indirectly by the following sequence of potential pulses using the MPA detection and FIA. Figure 2A presents the scheme of the pulse-waveform applied to the system for the simultaneous determination of DI and PCT.

For DI determination, the first applied potential pulse $(+0.40 \mathrm{~V}$ per $100 \mathrm{~ms})$ is appropriate for its quantification without interference of PCT. The second potential pulse $(+0.65 \mathrm{~V}$ per $100 \mathrm{~ms})$ is applied only for the electrochemical generation of NABQ which is afterwards detected in the cathodic region. The third potential pulse $(0.00 \mathrm{~V}$ per $200 \mathrm{~ms}$ ), as can be verified in Figure 1B, is related to the electrochemical reduction of the oxidation product from both analytes (DI and PCT). However, the cathodic current originated from the reduction of the DI oxidation product is of lower intensity. It can be observed also that the reduction current of both compounds decreases with the increase of the potential pulse time because the acquisition of the current signal is carried out at the end of the potential pulse. The decrease of the current is due to the phenomenon of mass transport (diffusion and mainly convection). The artifice used for the selective detection of PCT at this potential pulse was the acquisition of the current signal after $200 \mathrm{~ms}$ at a flow rate of $1.5 \mathrm{~mL} \mathrm{~min}^{-1}$. As can be seen in Figure 1B, the current originated by the reduction of the oxidation product of DI, at this time, falls close to zero and the current signal for the reduced NABQ (PCT oxidation product) can then be obtained without interference of DI. This condition is only true for DI concentrations smaller than $45 \mathrm{mg} \mathrm{L}^{-1}$. Another point to be considered is that this acquisition time is dependent on the flow rate, as the greater the flow rate, the lower should be the time and viceversa. A fourth potential pulse is necessary $(-0.05 \mathrm{~V}$ per $400 \mathrm{~ms}$ ) for the total removal of NABQ adsorbed on the electrode surface (cleaning). This step is required to avoid interferences on the DI oxidation signal and to maintain the repeatability of the results.

Figure $2 \mathrm{C}$ shows the amperograms obtained at $+0.40 \mathrm{~V}$ and $0.00 \mathrm{~V}$ for duplicate injections of three solutions with different compositions. The amperometric signals generated at $+0.65 \mathrm{~V}$ and $-0.05 \mathrm{~V}$ are not presented. In the first injection (Figure 2Ca), the solution contains only DI (45 mg L ${ }^{-1}$ ), the second (Figure 2Cb), only PCT (30 $\mathrm{mg} \mathrm{L}^{-1}$ ) and, the third (Figure $2 \mathrm{Cc}$ ), both analytes have the same concentrations of the previous solutions. As can be seen in Figure $2 \mathrm{C}$, at $+0.40 \mathrm{~V}$ only DI can be detected and at $0.00 \mathrm{~V}$, only PCT by the reduction of the NABQ, without the interference of DI.

In the studies conducted previously, the concentration of DI was 1.5 times higher than PCT. This relationship was previously defined based on the ratio between these compounds in commercial pharmaceutical formulations available in Brazil. However, the performance of the methodology was also evaluated for situations in which the ratio between concentrations of these compounds was different from previous experiment. Therefore, two studies were executed and results are shown in Figure 3. Initially, the concentration of DI varied from 9 to $180 \mathrm{mg} \mathrm{L}^{-1}(\mathrm{a}-\mathrm{g})$, maintaining PCT concentration constant at $6 \mathrm{mg} \mathrm{L}^{-1}$ (I).
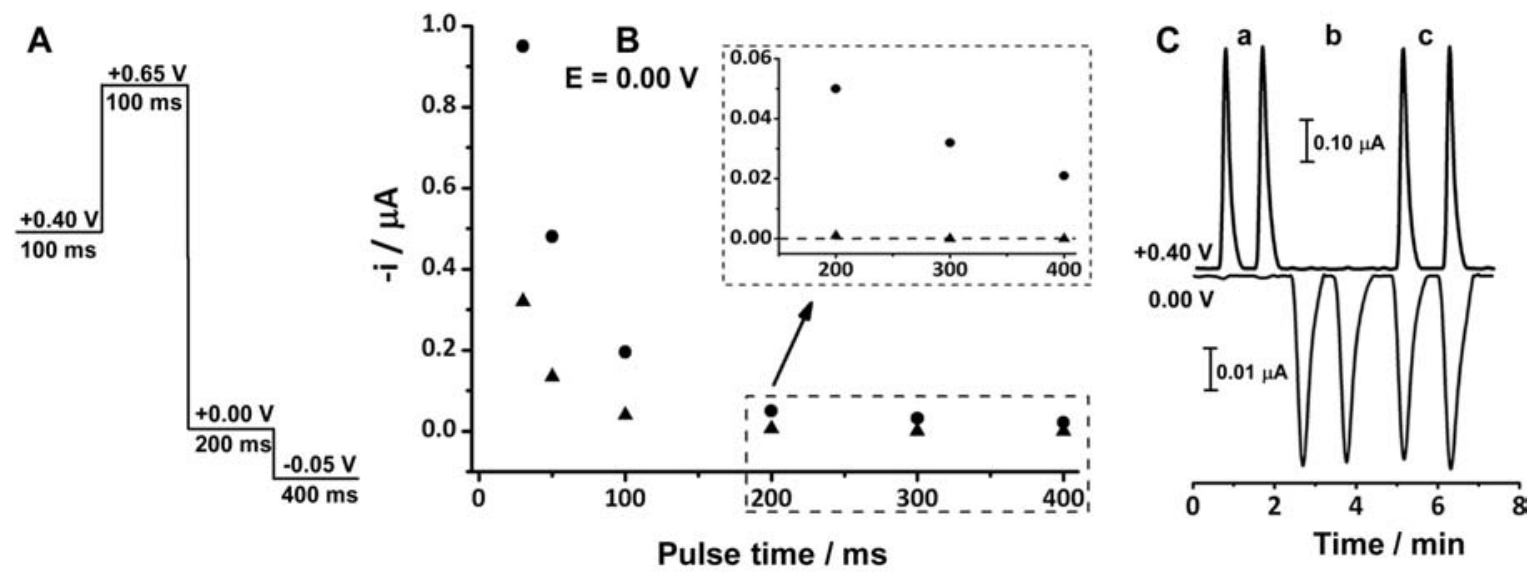

Figure 2. (A) Scheme of the waveform employed in the flow injection system with pulsed amperometric detection for simultaneous detection of DI and PCT. (B) Amperometric response at $0.00 \mathrm{~V}$ for the reduction of both NABQ (•) and the oxidation product of dipyrone ( $\mathbf{A}$ ). (C) Transient signals obtained for injections of standard solutions, in duplicate, containing (a) $45 \mathrm{mg} \mathrm{L}^{-1}$ of DI; (b) $30 \mathrm{mg} \mathrm{L}^{-1}$ of PCT, and (c) a mixture (45:30 mg L-1) of DI and PCT, respectively. The current signals at $+0.65 \mathrm{~V}$ and $-0.05 \mathrm{~V}$ are not presented. Carrier stream: $0.1 \mathrm{~mol} \mathrm{\textrm {L } ^ { - 1 }}$ acetic acid/acetate buffer ( $\mathrm{pH} 4.7$ ); Flow rate: $1.5 \mathrm{~mL} \mathrm{~min}^{-1}$; Injection volume: $150 \mu \mathrm{L}$; Working electrode: glassy carbon. 
Then, the concentration of PCT was changed between 6 and $120 \mathrm{mg} \mathrm{L}^{-1}$ (I to VII), keeping DI concentration constant at $9 \mathrm{mg} \mathrm{L}^{-1}$ (a).

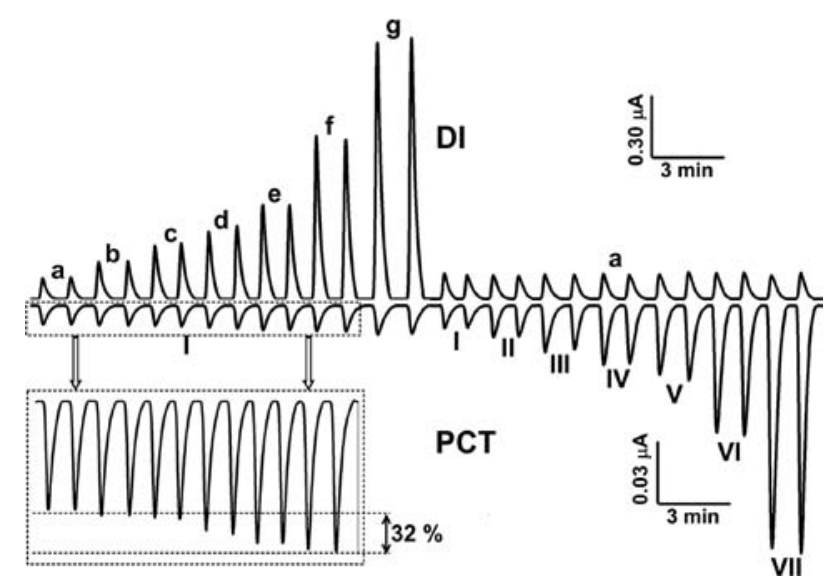

Figure 3. Amperometric response obtained for injections of standard solutions, in duplicate, containing increasing concentrations of DI $(\mathrm{a}=9$, $\mathrm{b}=18, \mathrm{c}=27, \mathrm{~d}=36, \mathrm{e}=45, \mathrm{f}=90, \mathrm{~g}=180 \mathrm{mg} \mathrm{L}^{-1}$ ) and a constant concentration of PCT $\left(\mathrm{I}=6 \mathrm{mg} \mathrm{L}^{-1}\right)$. Afterwards, standard solutions with increasing concentrations of PCT $(\mathrm{I}=6, \mathrm{II}=12, \mathrm{III}=18, \mathrm{IV}=24, \mathrm{~V}=30$, $\mathrm{VI}=60, \mathrm{VII}=120 \mathrm{mg} \mathrm{L}^{-1}$ ) and a constant concentration of DI. Other conditions as in Figure 2.

As can be seen, when the concentration of DI is fifteen times higher than PCT (f: 6 and $90 \mathrm{mg} \mathrm{L}^{-1}$ for PCT and DI, respectively), the PCT reduction signal increases significantly ( $c a .32 .0 \%)$. This can be explained by the start of the contribution of DI to the reduction signal, because at this concentration $\left(90 \mathrm{mg} \mathrm{L}^{-1}\right)$, the potential pulse duration $(200 \mathrm{~ms})$ is not long enough to remove completely the DI oxidation product from the electrode surface (flow system). Hence, considering these results, we can affirm that only pharmaceutical formulations presenting a DI/PCT ratio < 15 can be analyzed by the proposed method. It is noteworthy that, when applying a pulse duration greater than $200 \mathrm{~ms}$ to improve removal of the DI interference, the sensitivity for the indirect PCT detection is significantly affected (current decrease), making this alternative impracticable (Figure 2B). However, when the concentration of PCT is varied and the concentration of DI is maintained constant, as in Figure 3 (I to VII), no change in DI oxidation signal is observed. Exploratory studies with higher PCT concentrations showed that only when PCT/ DI ratio is equal to 100 , a decrease of around $10 \%$ in the oxidation signal of DI was noted. This decrease of the signal can be justified by electrode surface contamination due to the presence of high PCT concentrations, as a result of the inefficient cleaning potential pulse $(-0.05 \mathrm{~V}$ per $400 \mathrm{~ms})$ for removal of the adsorbed analyte (PCT). One way to avoid this contamination is to increase the duration of the cleaning pulse, since this option does not interfere with the other selected potential pulses. Thus, under these conditions, $\mathrm{PCT}$ is not considered as an interfering molecule on the analysis of DI.

The investigation of the repeatability of the current signal for DI and PCT was evaluated by injecting standard solutions containing both analytes. Figure 4 shows the FIA peaks obtained for 24 consecutive injections of a solution containing $45 \mathrm{mg} \mathrm{L}^{-1}$ of DI and $30 \mathrm{mg} \mathrm{L}^{-1}$ of PCT. The relative standard deviations were calculated at $0.4 \%$ and $0.2 \%$ for DI and PCT, respectively. In spite of the use of a bare glassy carbon electrode (with no chemical or electrochemical modification), the method does not present problems as poisoning or fouling processes which could cause reduction of the electrochemical signal with time. These results were only possible due to the use of a fourth potential pulse $(-0.05 \mathrm{~V}$ per $400 \mathrm{~ms})$ which is responsible for the constant cleaning of the electrode surface.

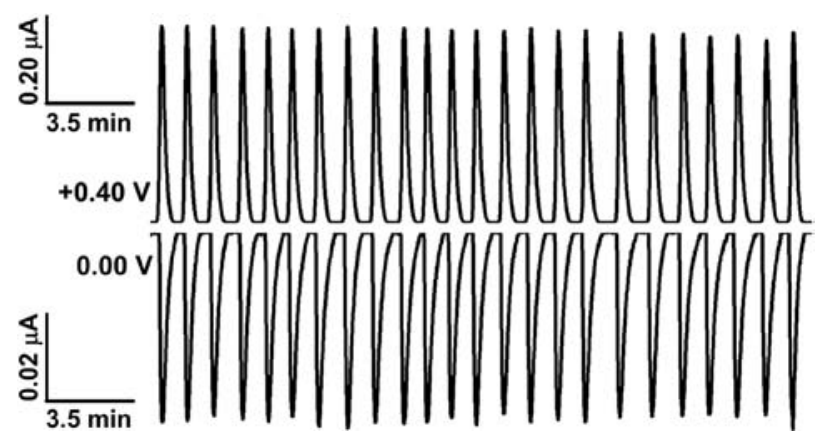

Figure 4. Responses obtained for 24 successive injections of $150 \mu \mathrm{L}$ aliquots of a solution containing DI and PCT (45 and $30 \mathrm{mg} \mathrm{L}^{-1}$, respectively) in acetic acid/acetate buffer ( $\mathrm{pH}$ 4.7). The relative standard deviations for dipyrone oxidation and NABQ reduction were calculated as $0.4 \%$ and $0.2 \%$, respectively. Other conditions as in Figure 2.

The analytical curve for the simultaneous quantification of dipyrone and paracetamol was implemented considering the previous results. Figure 5 presents the amperograms obtained using the proposed method for injections of standard solutions (in triplicate) containing both DI (a-e: 9 to $45 \mathrm{mg} \mathrm{L}^{-1}$ ) and PCT (a-e: 6 to $30 \mathrm{mg} \mathrm{L}^{-1}$ ) and their respective calibration curves. Both curves presented excellent linear correlation coefficient in the studied ranges $(\mathrm{R}=0999)$. The linear regression equation for DI was $\mathrm{I}(\mu \mathrm{A})=0.0029( \pm 0.0019)+0.01103\left( \pm 7.15 \times 10^{-5}\right) \mathrm{x}$ and for PCT was $\mathrm{I}(\mu \mathrm{A})=5.85 \times 10^{-5}\left( \pm 3.09 \times 10^{-4}\right)+0.00168$ $\left( \pm 1.70 \times 10^{-5}\right) \mathrm{x}$. The limits of quantification (10 times the standard deviation of the blank $)^{36}$ were calculated as 0.45 and $2.0 \mathrm{mg} \mathrm{L}^{-1}$ for DI and PCT, respectively. These limits are quite reasonable, because commercially-available drugs present higher concentrations of both compounds in their formulations. Under the conditions shown in Figure 5, the analytical frequency of the proposed method was calculated as 45 injections per hour. 

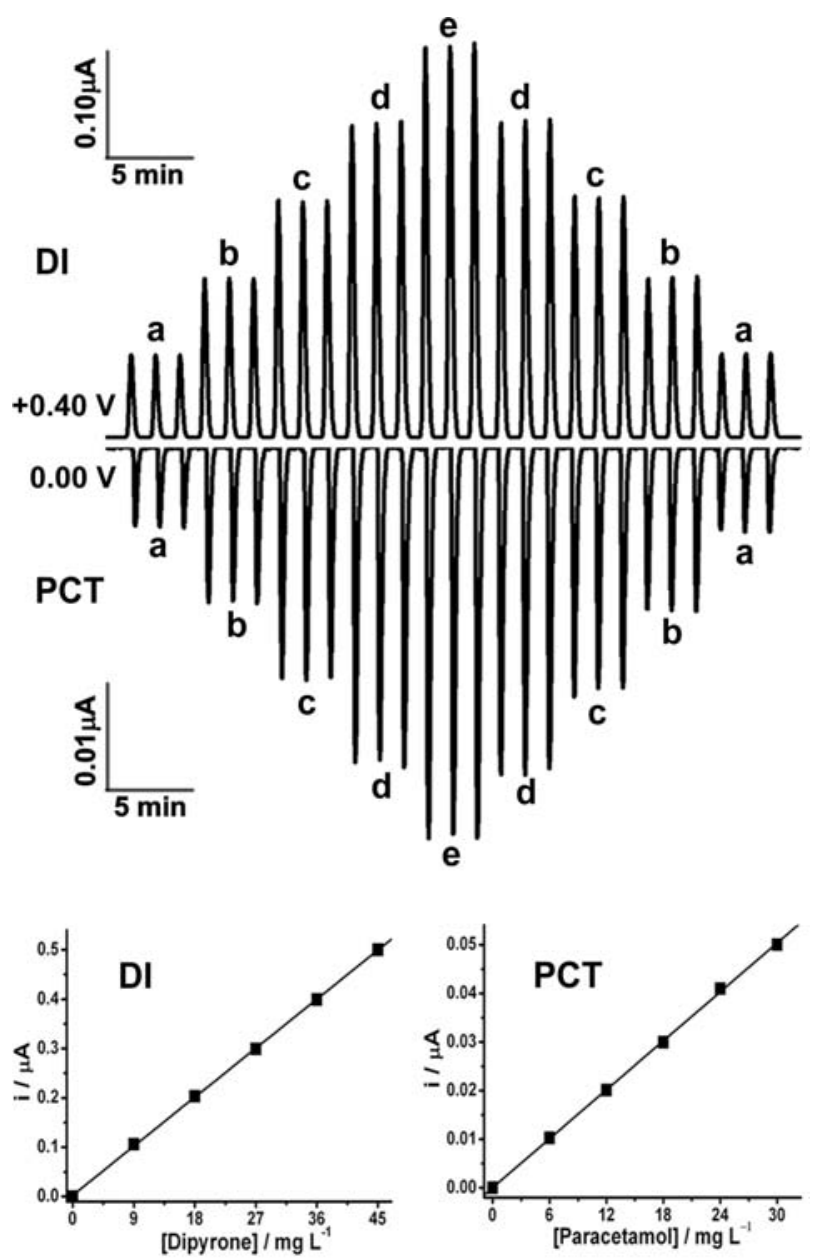

Figure 5. Amperograms and the respective calibration curves for standard solutions containing both DI (a-e: 9 a $45 \mathrm{mg} \mathrm{L}^{-1}$ ) and PCT (a-e: 6 a $30 \mathrm{mg} \mathrm{L}^{-1}$ ). $\mathrm{R}=0.999$ for both curves.

The proposed methodology for simultaneous determination of DI and PCT by FIA with MPA detection was assessed with five different pharmaceutical formulations, two of those containing only DI, two with only PA and one with a mixture of the two analytes. An artificial mixture with a different proportion between PCT and DI was also analyzed. Table 1 shows the results for the analysis of these samples $(n=4)$ with their respective standard deviations.
These results were compared with the nominal values on the label of each brand and sometimes with methods specified by the Pharmacopoeia, such as the determination of dipyrone by iodometric titration, ${ }^{7}$ and sometimes using previously published methods, such as the determination of paracetamol by titration with $\mathrm{Ce}^{4+}$ solution. ${ }^{22}$

As can be noted in Table 1, no significant differences between the two methods (pulsed amperometry and titration) were observed, which indicates the absence of systematic errors. The analysis of an artificial sample for which the concentration of the two analytes is different from the real sample also generated satisfactory results, with a recovery rate of 99.3 and $98.8 \%$ for PCT and DI, respectively. Additionally, spiking and recovery studies were carried out and values close to $100 \%$ were obtained in all tests.

\section{Conclusions}

This work presented a new method for simultaneous determination of dipyrone and paracetamol in pharmaceuticals formulations using flow injection analysis with multiple pulse amperometric detection. The application of an appropriate potential waveform allows the direct and selective detection of dipyrone and the indirect and selective detection of paracetamol in the same sample. The proposed methodology is simple, fast, cheap, and does not require any sample preparation. This method has a good potential to be applied in routine analysis in substitution of expensive chromatographic separation systems or laborious titration methods. A limitation of the present method occurs for samples in which the DI concentration is fifteen or more times higher that the PCT concentration. For this condition, DI also presents a reduction signal in the potential pulse where PCT is indirectly detected.

\section{Acknowledgments}

The authors thank Fundação de Apoio à Pesquisa do Estado de Minas Gerais (FAPEMIG), Coordenação de

Table 1. Results of the determination of DI and PCT in pharmaceutical formulations

\begin{tabular}{|c|c|c|c|c|}
\hline Sample & Analyte & Proposed method $^{\mathrm{a}} \mathrm{mg} /$ tablet & Comparison method ${ }^{\mathrm{a}} \mathrm{mg} /$ tablet & Labeled value mg / tablet \\
\hline 1 & PCT & $676.3(2.6)$ & $691.3(2.3)$ & 750 \\
\hline 2 & PCT & $740.0(2.4)$ & $720.8(2.5)$ & 750 \\
\hline 3 & DI & $226.9(2.6)$ & $220.6(3.0)$ & 300 \\
\hline 4 & DI & $519.5(2.5)$ & $517.8(3.1)$ & 500 \\
\hline 5 & PCT DI & $337.6(2.7) 490.1(2.8)$ & $344.0(2.5) 482.5(3.0)$ & 325500 \\
\hline Artificial mixture & PCT DI & $198.6(0.3) 395.2(0.4)$ & $199.5(0.6) 396.0(1.2)$ & $200^{\mathrm{b}} 400^{\mathrm{b}}$ \\
\hline
\end{tabular}

${ }^{a}$ The values in parentheses are the relative standard deviations $(n=4)$; ${ }^{b}$ Added concentrations; Comparison methods: iodometric titration for DI and titration with $\mathrm{Ce}^{4+}$ solution for PCT. 
Aperfeiçoamento de Pessoal de Nível Superior (CAPES) and Conselho Nacional de Desenvolvimento Científico e Tecnológico (CNPq) for financial support and Dr. Julien F. C. Boodts for the English revision.

\section{References}

1. Bentur, Y.; Cohen, O.; J. Toxicol. Clin. Toxicol. 2004, 42, 261.

2. Ergun, H.; Frattarelli, D. A. C.; Aranda, J. V.; J. Pharm. Biomed. Anal. 2004, 35, 479.

3. Bosch, M. E.; Sanchez, A. J. R.; Rojas, F. S.; Ojeda, C. B.; J. Pharm. Biomed. Anal. 2006, 42, 291; Dinc, E.; Baleanu, D.; J. Braz. Chem. Soc. 2008, 19, 434; Cervini, P.; Cavalheiro, E. T. G.; J. Braz. Chem. Soc. 2008, 19, 836.

4. Ramirez, A. M. D.; Delgadillo, G. P. H.; Martinez, R. V.; Reval, M. I. D.; Lopez-Munoz, F. J.; Drug Dev. Res. 2000, 51, 260.

5. Yang, X. X.; Hu, Z. P.; Duan, W.; Zhu, Y. Z.; Zhou, S. F.; Curr. Pharm. Des. 2006, 12, 4649.

6. Blier, P.; J. Psychopharmacol. 2007, 21, 459.

7. Farmacopéia Brasileira, $3^{\text {rd }}$ ed., Atheneu Editora: São Paulo, Brasil, 1977, p. 406.

8. European Pharmacopeia, Council of Europe, v.2, France, 2005, p. 2002.

9. Baranowska, I.; Markowski, P.; Baranowski, J.; Anal. Chim. Acta 2006, 570, 46.

10. Senyuva, H. Z.; Aksahin, I.; Ozcan, S.; Kabasakal, B. V.; Anal. Chim. Acta 2005, 547, 73.

11. Teixeira, M. F. S.; Marcolino-Junior, L. H.; Fatibello, O.; Dockal, E. R.; Cavalheiro, E. T. G.; J. Braz. Chem. Soc. 2004, 15, 803; Ferreira, H. E. A.; Daniel, D; Bertotti, M.; Richter, E. M.; J. Braz. Chem. Soc. 2008, 19, 1538; Sotomayor, M. D. P. T.; Sigoli, A.; Lanza, M. R.V.; Tanaka, A. A.; Kubota, L. T.; J. Braz. Chem. Soc. 2008, 19, 734.

12. Belal, F.; Electroanalysis 1992, 4, 589.

13. do Nascimento, A. P.; Trevisan, M. G.; Kedor-Hackmann, E. R. M.; Poppi, R. J.; Anal. Lett. 2007, 40, 975; Di Nezio, M. S.; Pistonesi, M. F.; Centurión, M. E.; Palomeque, M. E.; Lista, A. G.; Band, B. S. F.; J. Braz. Chem. Soc. 2007, 18, 1439.

14. Lima, J.; Sa, S. M. O.; Santos, J. L. M.; Zagatto, E. A. G.; J. Pharm. Biomed. Anal. 2003, 32, 1011.

15. Matos, R. C.; Angnes, L.; Araujo, M. C. U.; Saldanha, T. C. B.; Analyst 2000, 125, 2011.

16. Pereira, A. V.; Penckowski, L.; Vosgerau, M.; Sassa, M. F.; Fatibello, O.; Quim. Nova 2002, 25, 553.
17. Munoz, R. A. A.; Matos, R. C.; Angnes, L.; J. Pharm. Sci. 2001, 90, 1972.

18. Daniel, D.; Gutz, I. G. R.; Anal. Chim. Acta 2006, 571, 218.

19. Marcolino, L. H.; Bonifacio, V. G.; Fatibello-Filho, O.; Teixeira, M. F. S.; Quim. Nova 2005, 28, 783; Weinert, P. L.; Pezza, L.; Pezza, H. R.; J. Braz. Chem. Soc. 2007, 18, 846.

20. Medeiros, E. P.; Castro, S. L.; Formiga, F. M.; Santos, S. R. B.; Araujo, M. C. U.; Nascimento, V.B.; Microchem. J. 2004, 78, 91.

21. The United States Pharmacopoeia, U.S.P. 25 rev., The United States Pharmacopoeia Convention: Rockville, 2002.

22. Srivastava, M. K.; Ahmad, S.; Singh, D.; Shukla, I. C.; Analyst 1985, 110, 735 .

23. Altun, M. L.; Turk. J. Chem. 2002, 26, 521.

24. Golubitskii, G. B.; Budko, E. V.; Ivanov, V. M.; J. Anal. Chem. 2005, 60, 961.

25. Hlabangana, L.; Hernandez-Cassou, S.; Saurina, J.; Curr. Pharm. Anal. 2006, 2, 127; Skeika, T.; Ferreira de Faria, M., Nagata, N.; Pessoa, C. A.; J. Braz. Chem. Soc. 2008, 19, 762.

26. Galli, A.; de Souza, D.; Garbellini, G. S.; Coutinho, C. F. B.; Mazo, L.H.; Avaca, L. A.; Machado, S. A. S.; Quim. Nova 2006, 29, 105.

27. Chailapakul, O.; Ngamukot, P.; Yoosamran, A.; Siangproh, W.; Wangfuengkanagul, N.; Sensors 2006, 6, 1383.

28. Trojanowicz, M.; Szewczynska, M.; Wcislo, M.; Electroanalysis 2003, 15, 347.

29. de Carvalho, R. M.; Freire, R. S.; Rath, S.; Kubota, L. T.; J. Pharm. Biomed. Anal. 2004, 34, 871.

30. Surareungchai, W.; Deepunya, W.; Tasakorn, P.; Anal. Chim. Acta 2001, 448, 215.

31. Chang, C. M.; Huang, H. J.; Anal. Chem. 2003, 75, 6368.

32. dos Santos, W. T. P.; de Almeida, E. G. N.; Ferreira, H. E. A.; Gimenes, D. T.; Richter, E. M.; Electroanalysis 2008, 20, 1878 .

33. dos Santos, W. T. P.; Ceolin, M. P.; de Albuquerque, Y. D. T.; Richter, E. M.; Quim. Nova 2007, 30, 1754.

34. Pedrotti, J. J.; Angnes, L.; Gutz, I. G. R.; Electroanalysis 1996, 8, 673.

35. Miner, D. J.; Rice, J. R.; Riggin, R. M.; Kissinger, P. T.; Anal. Chem. 1981, 53, 2258.

36. Miller, J. C.; Miller, J. N.; Statistics for Analytical Chemistry, Harwood: Chichester, 1992.

Received: August 22, 2008 Web Release Date: May 22, 2009 